\title{
Shunt Active and Series Active Filters-Based Power Quality Conditioner for Matrix Converter
}

\author{
P. Jeno Paul \\ Department of Electrical and Electronics Engineering, Noorul Islam University, Tamilnadu 629001, India \\ Correspondence should be addressed to P. Jeno Paul, jenopaul1@rediffmail.com
}

Received 25 November 2010; Revised 2 February 2011; Accepted 6 May 2011

Academic Editor: King Jet Tseng

Copyright () 2011 P. Jeno Paul. This is an open access article distributed under the Creative Commons Attribution License, which permits unrestricted use, distribution, and reproduction in any medium, provided the original work is properly cited.

This paper proposes a series active filter and shunt active filter to minimize the power quality impact present in matrix converters instead of passive filter. A matrix converter produces significant harmonics and nonstandard frequency components into load. The proposed system compensates the sag and swell problems efficiently in matrix converter. The proposed system has been tested and validated on the matrix converter using MATLAB/Simulink software. Simulated results confirm that the active power filters can maintain high performance for matrix converter.

\section{Introduction}

Power quality is a set of limits or conditions of electrical properties that allows electrical devices to function in their planned manner without loss of performance. Without the proper power, an electrical utility may malfunction, fail permanently, or not operate well. There are many possible ways in which electric power can be of poor quality and many more causes or effects of such poor, quality power [1]. Ideally, the voltage is fed as a sinusoidal having a magnitude and a frequency given by the international standards or system specifications with impedance of zero ohms at all frequencies. Power quality disturbance is produced by the inverters and the converters [2]. A matrix converter is a three to three-phase configuration and is just one of the possible direct AC-AC converter topologies [3].

Matrix converter has several advantages over traditional rectifier-inverter type power frequency converters. It provides sinusoidal input and output waveforms. It has inherent bi-directional energy flow capability; the input power factor can be fully controlled. Finally, it has minimal energy storage requirements, which allows to get rid of bulky and lifetime limited energy-storing capacitors. In spite of the advantages the matrix converter has also some disadvantages. It has a maximum input-output voltage transfer ratio limited up to $87 \%$ for a sinusoidal input and output waveforms. It requires more semiconductor devices than a conventional AC-AC indirect power frequency converter, since no monolithic bidirectional switches exist and the discrete unidirectional devices are arranged. So it can be used for each bidirectional switch. The matrix converter consists of 9 bi-directional switches [4] that allows any output phase to be connected to any input phase. Figure 1 shows the block diagram of a matrix converter feeding a standalone load. The threephase AC line voltage is applied to the matrix converter after appropriate filtering. The matrix converter converts the fixed voltage to voltage with variable amplitude and frequency. The output can be supplied to any load that requires variable voltage with variable frequencies such as to drive an induction motor and the permanent magnet synchronous motor. Matrix converter has several advantages, but it may also produce high-order harmonics [5]. Conventional harmonics mitigation like series passive and shunt active filter have some drawback, these passive filters are not stable in supply frequency variations. Because the matrix converter output is the variable voltage and the variable frequency supply, so passive filters are easily make the resonance in the matrix converter output. In order to overcome these problems active filtering technique method is proposed. The advantage of active filtering technology is used to minimize the inductance value. Passive filters without inductors cannot obtain a high Q factor (low damping), but with inductor, it is very expensive at low frequencies. The proposed system is applicable for the place where the low harmonics and high accurate power regulation is needed. 


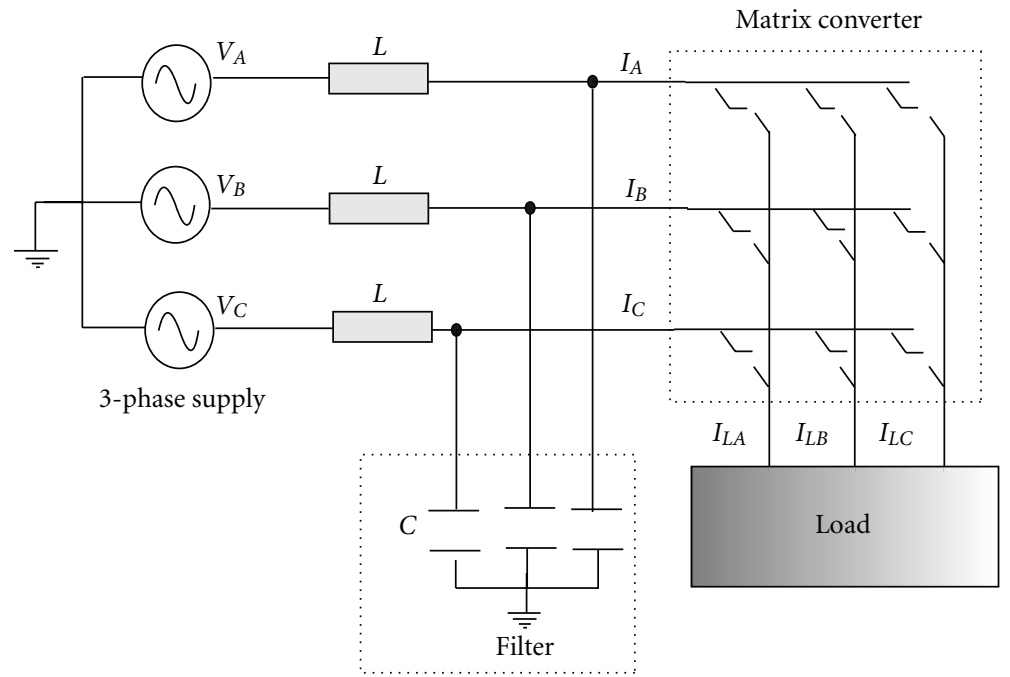

FIGURE 1: The General architecture of matrix converter.

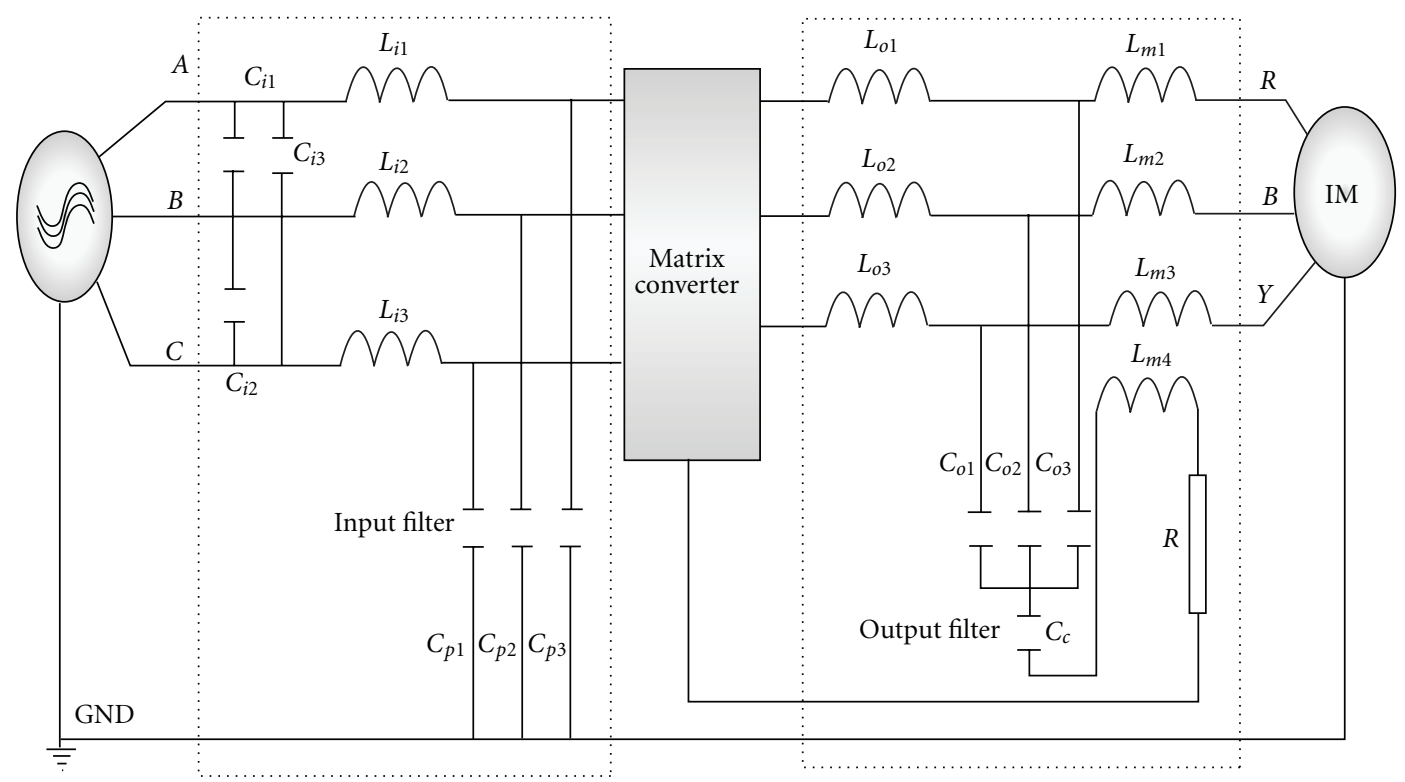

FIGURE 2: Existing technique of power quality improvement for the matrix converter.

\section{General Structure and compensation Technique of Matrix Converter}

2.1. General Structure. A matrix converter is a variable amplitude and frequency power supply that converts the three-phase line voltage directly, that is without, intermediate DC-voltage or current link, into three-phase output voltage. It is very simple in structure and has powerful controllability. The converter consists of nine modular H-bridge capacitorclamped switch cells that are connected from each input phase to each output phase. The terminal AC voltages of the converter are synthesized from the modulation techniques of Space Vector Modulation. The space vector modulation approach is a well-known technique for control of threephase converters [6]. The switching pulses for the power devices in each bridge are obtained from the modulation techniques. The converter is capable of both increasing and decreasing the voltage magnitude and frequency, while operating with arbitrary power factors. Multilevel switching can be used to synthesize the voltage waveforms at both the input and output of the converter. The switch cells can be connected in series with branch of the matrix to increase the voltage rating of the converter. The converter is capable of increasing the number of levels of operation by connecting more than one switch cell in series.

2.2. Passive Filter Compensation. The principal method of reducing the harmonics generated by the static converter is provided by the input filter using reactive storage elements as shown in Figure 2. The problem of the input filter design for a matrix converter has been addressed in quite few papers [7-9] were looking at the literature. 


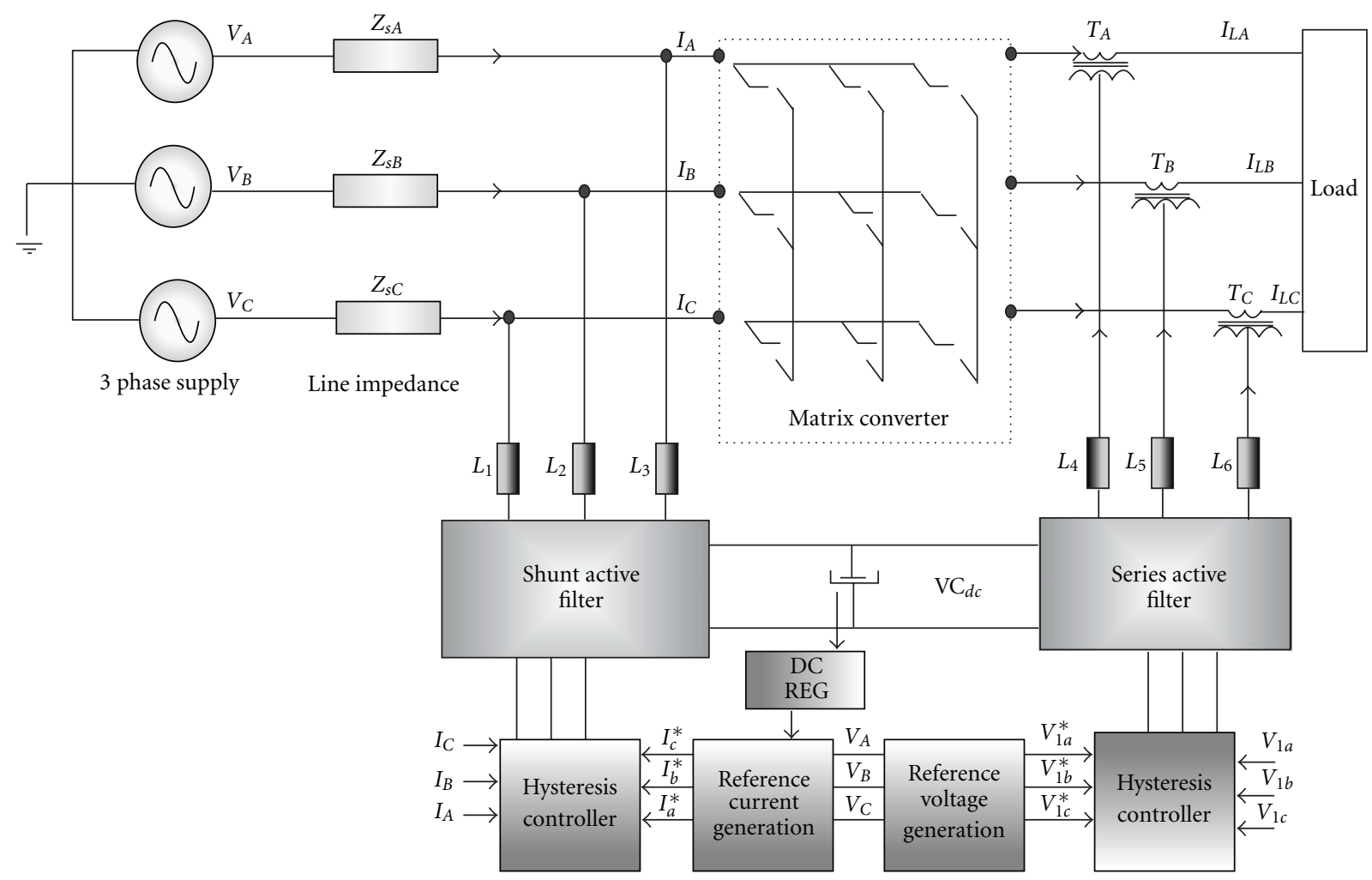

FIgURE 3: The proposed configuration for matrix converter.

So many configurations are proposed for the matrix converter input filter $[10,11]$. Such differences are a consequence of different design criteria, or at least differently weighted, different switching frequencies, and different modulation strategies. In order to meet the required attenuation requirement, there is an overall increase in filter size. Moreover, the input filter output impedance, related to the total filter capacitor value, is more difficult to control and leads to converter instability. As far as the matrix converter is concerned, a high displacement angle of the input line current due to the input filter capacitance component might be compensated by the matrix converter, setting as reference for the input current a lagging displacement angle. But in this way the maximum voltage transfer ratio for the converter will be significantly reduced. Therefore, even for the matrix converter, the upper limit of the input filter capacitance is set by the minimum acceptable AC main power factor. Similarly the control of the impedance interaction between the input filter and the voltage converter is necessary. In general, the filter output impedance should be as low when compared to the converter input impedance. The filter output impedance can be reduced by the filter capacitor size that may increase practically the impedance interaction constraint which determines the lower constraint on the filter capacitor value. In addition to the above proper filter pole damping is extremely important for achieving low-filter output impedance for all frequencies, and, the overall system stability may be improved. In general, an optimized design of the matrix converter input filter is a quite difficult task, since it relies on a system level approach, and in the light of the new coming harmonic and EMI reduction standards it can be considered as an outstanding issue.

\section{The Proposed Compensation Scheme for Matrix Converter}

The proposed technique includes two parts: the first part compensates matrix converter's input power quality problems, and the second part compensates matrix converter's output power quality problems. The matrix converter is considered as two types of load, that is, Current-Source Type of Harmonic Sources, Voltage-Source Type of Harmonic Sources. The enhanced control system is proposed to further eliminate harmonics with higher accuracy. Figure 3 shows the proposed compensation for matrix converter with a shunt active filter, source, and load when the filter is used to compensate the current harmonics produced by the matrix converter.

In Figure 3, $Z_{s A}, Z_{s B}, Z_{s C}$ are impedances of the source and shunt passive filter, respectively. $I_{\operatorname{Lh}(a . b . c)}, V_{\operatorname{Lh}(a, b . c)}$, and $V_{s h(a, b, c)}$ are the current harmonics of the load and voltage harmonics of the load and source harmonics, respectively. $I_{A F}$ is the current of the shunt active filter. The control system design of the shunt active power filter for matrix converter which cancels the harmonic in the supply current is shown in Figure 3. Shunt active filters are used to compensate current harmonics of nonlinear loads to perform reactive power compensation and to balance the imbalance currents. A shunt active filter senses the load current and injects a current 


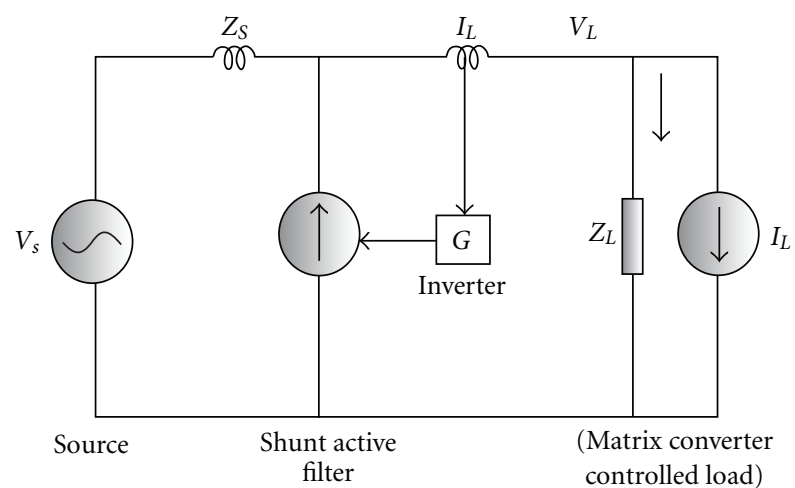

FIGURE 4: Principle of shunt active filter for matrix converter.

into the system to compensate current harmonics or reactive load. In this paper a shunt filter is used to compensate the current harmonics of matrix converter here the shunt active filter acts as a current source. The sum of its current and load current is the total current that flows through the source. Therefore, controlling the output current of the active filter can control the source current. A series active filter is used to eliminate the voltage harmonics produced by the matrix converter. When the load is sensitive and critical, a series converter is used to regulate line voltage for the load. It cancels out any line voltage distortions such as voltage harmonics, sag, swell, and voltage unbalance. It is capable of eliminating any voltage harmonics with a frequency within the bandwidth of the control scheme. For voltage sag (swell) compensation, active power must be delivered to (received from) the system. This active power is supplied (received) by the DC capacitor and creates a voltage ripple on the DC bus voltage. The second function of the series converter of UPQC, which is considered in very-high-power applications, is defined to protect the power system against the voltage distortions originating from the load. Some nonlinear loads, which usually have a capacitor bank after a bridge rectifier, appear to be the voltage harmonic generators. The voltage harmonics at the point of common coupling (PCC) affect the other sensitive loads connected to this point.

3.1. Current-Source Type of Harmonic Sources in Matrix Converter. Power electronic converters are a common and typical source of harmonic currents. The distortion of the current waveform, that is, the generation of harmonics, results from the switching operation. Because the harmonic current contents and characteristics are less dependent upon the AC side, this type of harmonic source behaves like a current source. Therefore, they are called current-source type of harmonic source (or harmonic current source) and represented as a current source. A shunt active filter is to be placed in parallel with a load (matrix converter) to detect the harmonic current of the load and to inject a harmonic current with the same amplitude of that of the load into the AC system. In order not to lose generality, the harmonic current source is represented as Norton's equivalent circuit. A pure current-source type of harmonic source is a special case of the Norton's equivalent with $Z_{L} \rightarrow \infty$.
Figure 4 shows the basic principle of a shunt active filter compensating for a harmonic current source, where the harmonic source is represented as Norton's equivalent, $Z_{s}$ is the source (line) impedance, $I_{L}$ is the equivalent harmonic current source, $Z_{L}$ is the equivalent impedance on the input side of matrix converter which may include passive filters and power factor correction capacitors, and $G$ is the equivalent transfer function of the active filter including the detection circuit of harmonics and the delay of the control circuit. In general, $G$ has the function of notching the fundamental component, that is, $|G|_{h}=0$ at the fundamental, and $|G|_{h}=$ $l$ for harmonics. In the following analysis, all equations are represented per unit. From Figure 4, the following equations are obtained

$$
\begin{gathered}
I_{c}=G I_{L}, \\
I_{S}=\frac{Z_{L}}{Z_{S}+\left(Z_{L} / 1-G\right)} \cdot I_{L O}+\frac{V_{S}}{Z_{S}+\left(Z_{L} / 1-G\right)}, \\
I_{L}=\frac{\left(Z_{L} / 1-G\right)}{Z_{S}+\left(Z_{L} / 1-G\right)} \cdot I_{L O}+\frac{V_{S}}{Z_{S}+\left(Z_{L} / 1-G\right)} .
\end{gathered}
$$

Focusing on harmonics

$$
\begin{gathered}
\left|\frac{Z_{L}}{1-G}\right|_{h}>\left|Z_{S}\right|_{h}, \\
I_{C}=I_{L h}, \\
I_{L h}=I_{L O h}+\frac{V_{S h}}{Z_{L}},
\end{gathered}
$$

where the subscripts, " $h$ " and " $f$ " represent the harmonic components and the fundamental components, respectively. Modulus represents the magnitude of a transfer function. $G$ can be predesigned and determined by the active filter while $Z_{s}$ and $Z_{L}$ are determined by the system, that is, parameters of the ac source and the load side of the matrix converter.

The most popular type of shunt active filter control system is proposed in the elimination of harmonics in active filter for matrix converter. Shunt active filters can be single-phase or three-phase voltage source or current source. Active filter compensates the harmonic current of a matrix converter, which produces harmonic current. The shunt active power filter control algorithm is shown in Figure 5. Instantaneous reactive power $(p-q)$ theory is used to control the shunt active power filter in real time. In this 


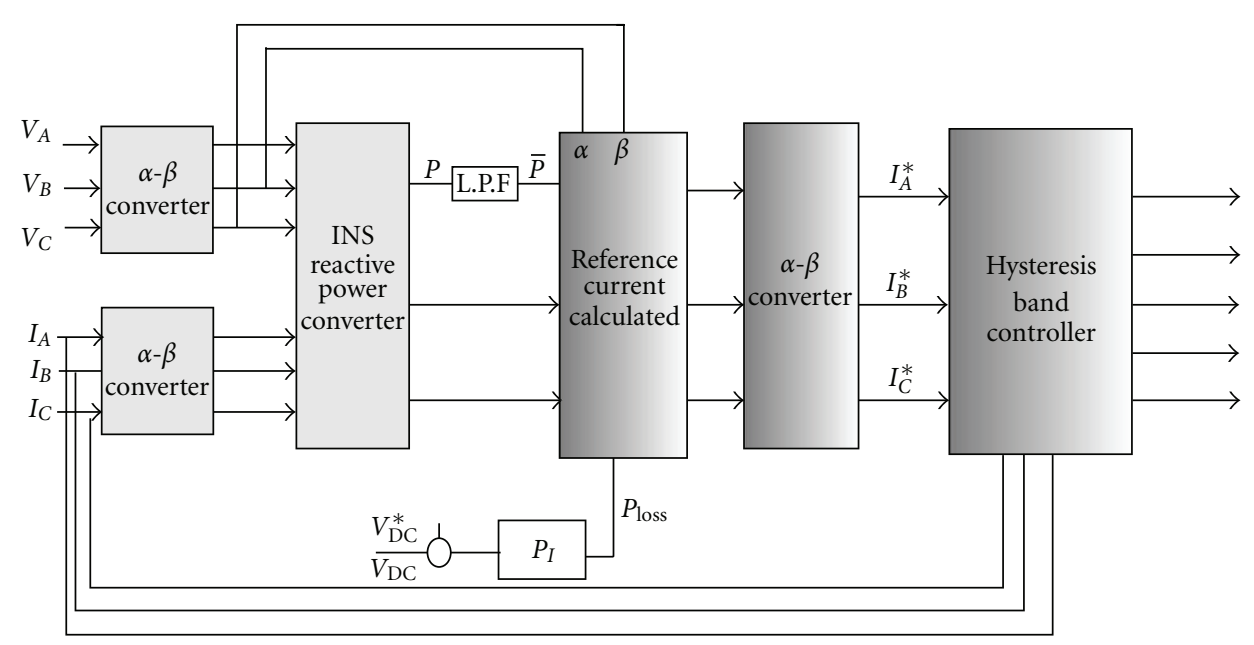

FIgURE 5: Control system of shunt active filter for matrix converter.

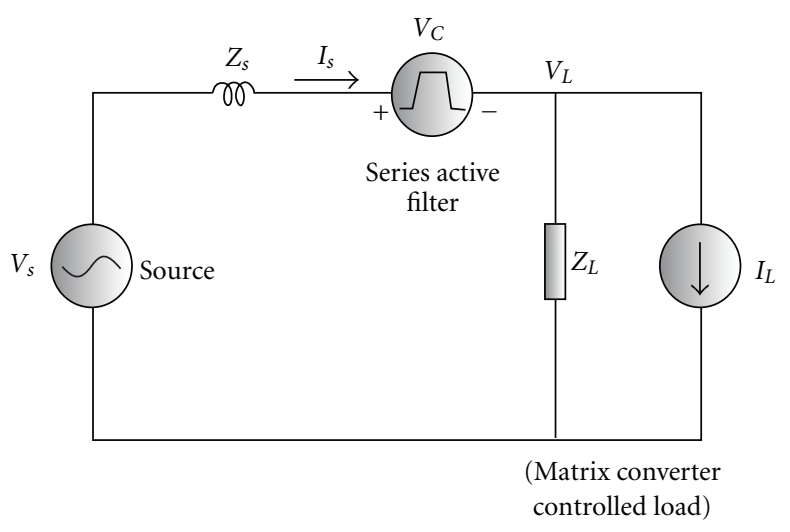

FIGURE 6: Principle of series active filter for matrix converter.

theory, instantaneous three-phase voltages and current are transformed to $\alpha-\beta-0$ from $a-b-c$ coordinates as shown in

$$
\begin{aligned}
& {\left[\begin{array}{l}
v_{o} \\
v_{\alpha} \\
v_{\beta}
\end{array}\right]=\sqrt{\frac{2}{3}}\left[\begin{array}{ccc}
\frac{1}{\sqrt{2}} & \frac{1}{\sqrt{2}} & \frac{1}{\sqrt{2}} \\
1 & -\frac{1}{2} & \frac{1}{\sqrt{2}} \\
0 & \frac{\sqrt{3}}{2} & -\frac{\sqrt{3}}{2}
\end{array}\right]\left[\begin{array}{l}
v_{s a} \\
v_{s b} \\
v_{s c}
\end{array}\right]} \\
& {\left[\begin{array}{l}
i_{o} \\
i_{\alpha} \\
i_{\beta}
\end{array}\right]=\sqrt{\frac{2}{3}}\left[\begin{array}{ccc}
\frac{1}{\sqrt{2}} & \frac{1}{\sqrt{2}} & \frac{1}{\sqrt{2}} \\
1 & -\frac{1}{2} & \frac{1}{\sqrt{2}} \\
0 & \frac{\sqrt{3}}{2} & -\frac{\sqrt{3}}{2}
\end{array}\right]\left[\begin{array}{l}
i_{s a} \\
i_{s b} \\
i_{s c}
\end{array}\right] .}
\end{aligned}
$$

Load side instantaneous real and imaginary power components are calculated by using source currents and phaseneutral voltages given

$$
\left[\begin{array}{c}
p_{0} \\
p \\
q
\end{array}\right]=\sqrt{\frac{2}{3}}\left[\begin{array}{ccc}
v_{0} & 0 & 0 \\
0 & v_{\alpha} & v_{\beta} \\
0 & -v_{\alpha} & v_{\beta}
\end{array}\right]\left[\begin{array}{c}
i_{0} \\
i_{\alpha} \\
i_{\beta}
\end{array}\right] .
$$

Instantaneous real and imaginary powers include both $\mathrm{AC}$ and DC components as shown in (4). DC components of $p$ and $q$ are obtained from positive sequence components ( $p$ and $q$ ) of load current. AC components $(\widetilde{P}$ and $\tilde{q})$ of $p$ and $q$ include harmonic and negative sequence components of load currents. In order to reduce neutral current, $p_{0}$ is calculated by using DC and AC components of imaginary power and the AC Component of real power, which is given in (5). If both harmonic and reactive power compensations are required,

$$
\begin{aligned}
& p_{0}=v_{0} \cdot i_{0} ; \quad p=\bar{p}+\tilde{p} ; \quad q=\bar{q}+\tilde{q}, \\
& {\left[\begin{array}{c}
i_{s \alpha}^{*} \\
i_{s \beta}^{*}
\end{array}\right]=\frac{1}{v_{\alpha}^{2}+v_{\beta}^{2}}\left[\begin{array}{cc}
v_{\alpha} & -v_{\beta} \\
v_{\beta} & v_{\alpha}
\end{array}\right]\left[\begin{array}{c}
\bar{p}+p_{0}+\bar{p}_{\text {loss }} \\
0
\end{array}\right] .}
\end{aligned}
$$

$i_{s \alpha}^{*}$ and $i_{s \beta}^{*}$ are reference currents of shunt active power filter in $\alpha-\beta-0$ coordinates. To compensate neutral current, $i_{s 0}^{*}=$ $-i_{0}$, these currents are transformed to three-phase system as shown in

$$
\left[\begin{array}{l}
i_{s a}^{*} \\
i_{s b}^{*} \\
i_{s c}^{*}
\end{array}\right]=\sqrt{\frac{2}{3}}\left[\begin{array}{ccc}
\frac{1}{\sqrt{2}} & 1 & 0 \\
\frac{1}{\sqrt{2}} & -\frac{1}{2} & \frac{\sqrt{3}}{2} \\
\frac{1}{\sqrt{2}} & -\frac{1}{2} & -\frac{\sqrt{3}}{2}
\end{array}\right]\left[\begin{array}{c}
i_{s 0}^{*} \\
i_{s \alpha}^{*} \\
i_{s \beta}^{*}
\end{array}\right] .
$$

The reference currents in three-phase system $\left(i_{s a}^{*}, i_{s b}^{*}\right.$ and $\left.i_{s c}^{*}\right)$ are calculated in order to compensate neutral, harmonic, and 


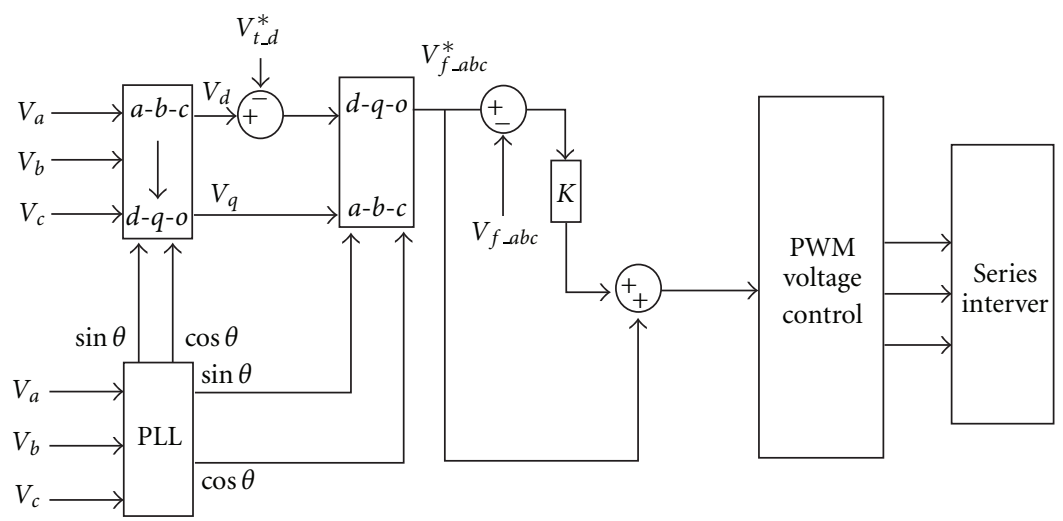

FIgURE 7: control system of series active filter for matrix converter.

TABle 1

\begin{tabular}{lc}
\hline Rated load power & $8 \mathrm{kvA}$ \\
Rated UPQC power & $10 \mathrm{kvA}$ \\
Shunt converter inductance & $2 \mathrm{mH}$ \\
dc-link capacitors & $2200 \mu \mathrm{F}$ \\
Series converter filter Inductance & $0.5 \mathrm{mH}$ \\
Series-converter filter Capacitor & $15 \mu \mathrm{F}$ \\
dc-link controlled voltage & $700 \mathrm{v}$ \\
Switching frequency & $10 \mathrm{kHz}$ \\
Matrix converter power rating & $10 \mathrm{kvA}$ \\
\hline
\end{tabular}

reactive currents in the load. The switching signals, which are used in shunt active power filter control algorithm are generated by comparing reference currents and actual line currents using hysteresis band current control algorithm.

\subsection{Voltage-Source Type of Harmonic Sources in Matrix Con-} verter. Another type of common harmonic source is matrix converter output, which produces harmonic voltage and current waveforms. Although the current is highly distorted, its harmonic amplitude is greatly affected by the impedance of the AC side. Therefore, the matrix converter output behaves like a voltage source harmonic. The harmonic voltage source is represented as Thevenin's equivalent circuit, as shown in Figure 6. A pure voltage-source type of harmonic source is a special case of Thevenin's equivalent with $Z_{L} \rightarrow 0$.

Figure 6 shows the basic principle of series active filters compensating for a harmonic voltage source. If the series active filter is controlled as

$$
V_{C}=K G I_{s}
$$

he source current is

$$
I_{S}=\frac{V_{S}-V_{L}}{Z_{S}+Z_{L}+K G}
$$

$K \gg 1$ is the operating condition for the series active filter to compensate for a harmonic source.

The series active filter control system for voltage type harmonic source compensation is proposed in this matrix converter. Figure 7 shows the proposed compensation scheme for matrix converter. The series converter is capable of suppressing the voltage harmonics of the load. The matrix converter has disadvantage, that is, the input voltage distortions directly affect the output voltage. The series converter deals with the input voltage distortions. It injects or receives active power for voltage sag or swell compensation. It also delivers a zero average instantaneous power for voltage harmonic cancelation. The voltage across the series converter is

$$
V_{f}=V_{\text {ref }}-V_{s}+\sum V_{h}=V_{s}(1-1 / k)+\sum V_{h}
$$

In (10) $k=V_{s} / V_{\text {ref }}$ and $V_{h}$ is the voltage harmonic of the source. All the voltages are instantaneous values. To indicate the effect of harmonics on the power rating of the converters, we define "characteristic power" instead of the apparent power. This term is defined as

$$
\mathrm{CS}=I_{\mathrm{rms}} V_{\mathrm{rms}}
$$

In (11) CS is the characteristic power and $I_{\mathrm{rms}}$ and $V_{\text {rms }}$ are effective values of current and voltage including harmonics. The value of $V_{\mathrm{rms}}$ for the output of the series converter is

$$
V_{\mathrm{rms}}=\left(v_{l}^{2}+\sum_{h}^{2}\right)^{1 / 2}=V_{s}\left[\left(1-\frac{1}{k}\right)^{2}+\mathrm{THD}_{v}^{2}\right]^{1 / 2} .
$$

In (12), where $V 1=V_{\text {ref- }} V_{s}$ considering only active current through the line, the characteristic power of each phase of the series converter is

$$
\mathrm{CS}_{\text {Series }}=v_{s} I_{l} \cos \theta \sqrt{\left(\frac{1}{K}-1\right)^{2}}+\mathrm{THD}_{v}^{2}
$$

where $\mathrm{THD}_{v}$ is the total harmonic distortion (THD) of the source voltage and defined as $\mathrm{THD}_{v}=\sqrt{\sum v_{h}^{2} / V_{s}}$, is the power factor of the load, and $I_{L}$ is the fundamental component of the load current. A series active filter senses the load voltage and injects the compensated voltages into the system to compensate voltage harmonics. In this paper 

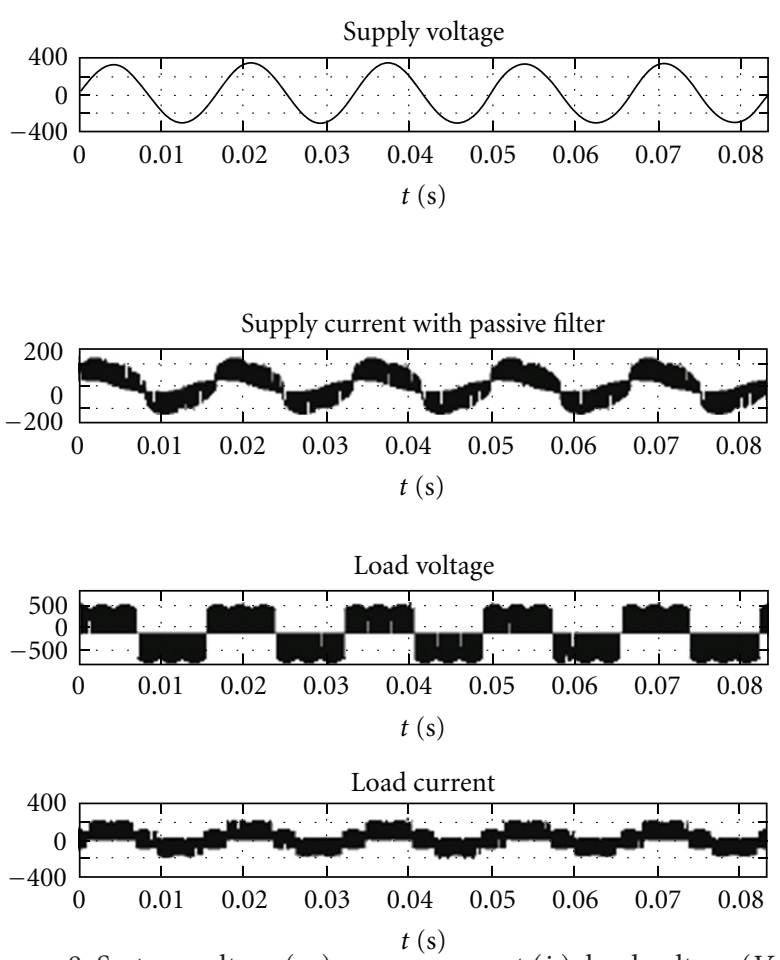

FIGURE 8: System voltage $\left(v_{S}\right)$, source current $\left(i_{s}\right)$, load voltage $\left(V_{L}\right)$, and load current $\left(I_{L}\right)$ with passive filter.

a series active filter is used to compensate the voltage harmonics of matrix converter. Matrix converter is sensitive to the disturbances of the input voltage. So the series active filter also compensates the imbalance voltage present in the output voltage. Figure 7 shows the series active filter controlling block diagram using synchronous reference frame theory. In this method the desired value of load phase voltage is in $\mathrm{d}$ axis and $\mathrm{q}$ axis is compared with the load voltage, and the result is considered as the reference signal. The supply voltage $\left(V_{a b c}\right)$ is detected and transformed into the synchronous $d q o$ reference frame using the relation

$$
v_{t_{-} d q o}=T_{a b c}^{d q o} v_{t_{-} a b c} .
$$
dqo.

The compensating reference voltage in the synchronous

reference frame is defined as

$$
v_{s f_{-} d q o}^{\mathrm{ref}}=v_{t_{-} d q o}-v_{l_{-} d q o}^{\exp }
$$

The compensating reference voltage in (6) is then transformed back into the $\left(a_{-} b_{-} c\right)$ reference frame. Resulted reference voltage $\left(v_{f a}^{*}, v i_{f b}^{*}, v_{f c}^{*}\right)$ and the output current of shunt inverter $\left(v_{f a}, v_{f b}, v_{f_{c}}\right)$ are fed to the hysteresis band controller. The required controlling pulses are generated, and the required compensation voltage is generated.

\section{Simulations Results}

In this section, the simulation results of the proposed active filters are discussed using the Matlab/Simulink software. Simulation was carried out for the resistive load.The proposed system parameters are described in Table 1.
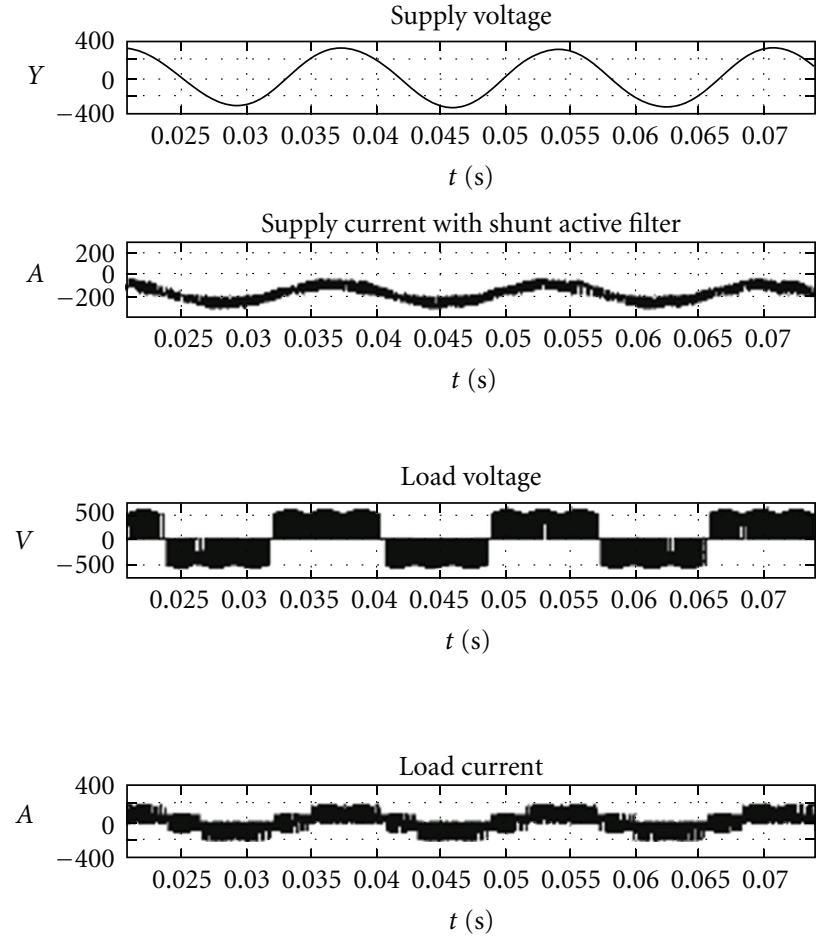

FIGURE 9: System voltage $\left(v_{S}\right)$, source current $\left(i_{S}\right)$ load voltage $\left(V_{L}\right)$ and load current $\left(I_{L}\right)$ when the shunt active filter is turned on.

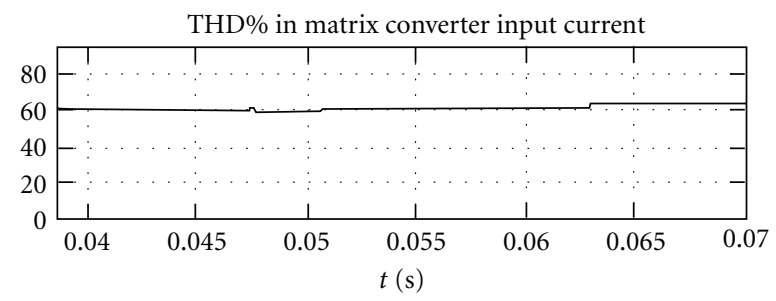

FIgURE 10: Total harmonic distortion with passive capacitor bank.

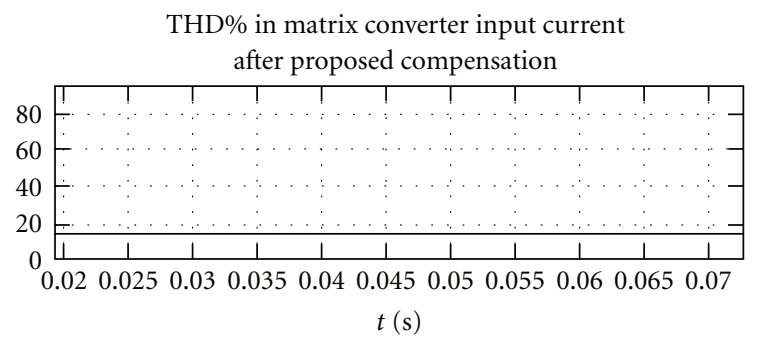

FIgURE 11: Total harmonic distortion proposed system.

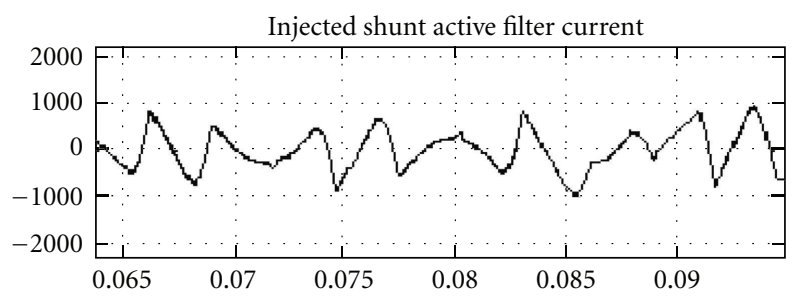

FIGURE 12: Current injected by the shunt active filter. 

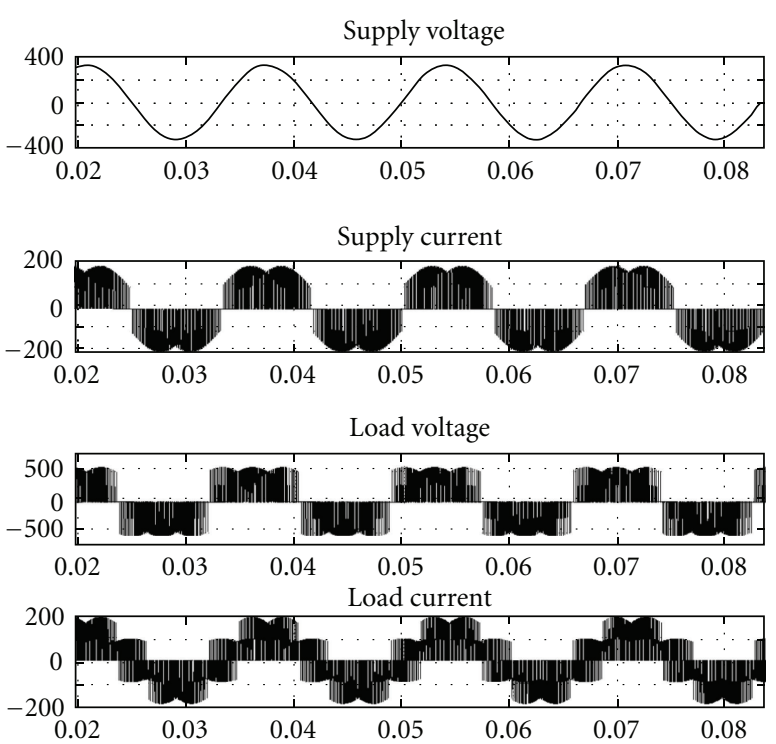

Figure 13: Supply voltage $\left(v_{S}\right)$, source current $\left(i_{S}\right)$ load voltage $\left(V_{L}\right)$ and load current $\left(I_{L}\right)$ without filter.

In Figure 8, the simulation of the matrix converter with passive input capacitor is shown. Here the input current waveform is non sinusoidal. The harmonics are not effectively eliminated by the fixed capacitor bank and the input current waveform obtained is nonsinusoidal. Consider the simulation time $0.025 \mathrm{sec}$ to $0.080 \mathrm{sec}$, the current waveform is non sinusoidal and it contain harmonics during the specified time.

Figure 9 shows the proposed shunt active power filter scheme that compensates the line current wave shape effectively when compared to the existing method effectively as shown in the simulation results. The total simulation time is $0.02 \mathrm{sec}$ to $0.085 \mathrm{Sec}$. In this simulation the current waveform is almost sinusoidal.

Figure 10 shows that the supply current harmonics are about 59\%. After the proposed shunt active filter is implemented, the supply current harmonics are reduced by $18 \%$ as shown in Figure 11.

So the power quality is maintained by using the shunt active filter. The proposed control strategy is that the system is connected to the $60 \mathrm{~Hz}$ utility and it transfers power to a resistive load.

Figure 12 shows the current injected by the shunt active filter. This compensation current is added to the harmonic current and compensates the load current. In the above simulation studies, the results are specified before and after active filter (AF) system is operated.

In Figure 13 the simulations of the matrix converter operates without the input capacitor is shown. Here the line voltage is $440 \mathrm{v}$. The supply current is 200 amperes. In this simulation the input current wave shape is non sinusoidal and it contains harmonics. The simulation time start, from 0.02 to 0.085 . Considers that the simulation time $0.025 \mathrm{sec}$ to $0.045 \mathrm{sec}$ is the one cycle of the current wave form. Here the wave shape of this current is non sinusoidal, and it contains harmonics.
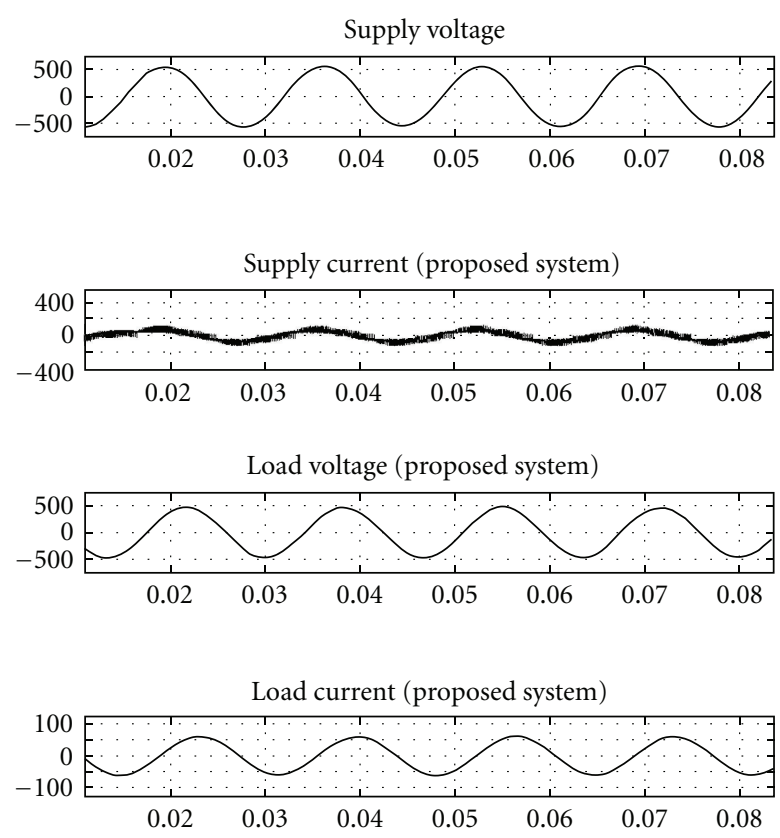

Figure 14: Load voltage $\left(V_{L}\right)$ and load current $\left(I_{L}\right)$ when the series active filter and shunt active are turned on.

THD\% in matrix converter output voltage before compensation

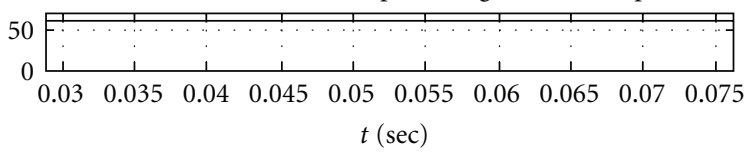

THD\% in matrix converter output after compensation

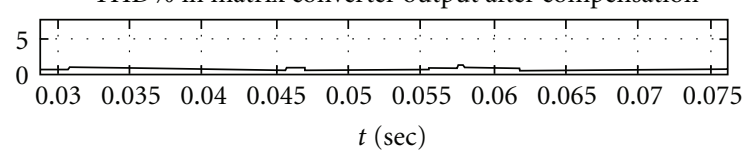

FIGURE 15: Total harmonic distortion in matrix converter output voltage without and with compensation.
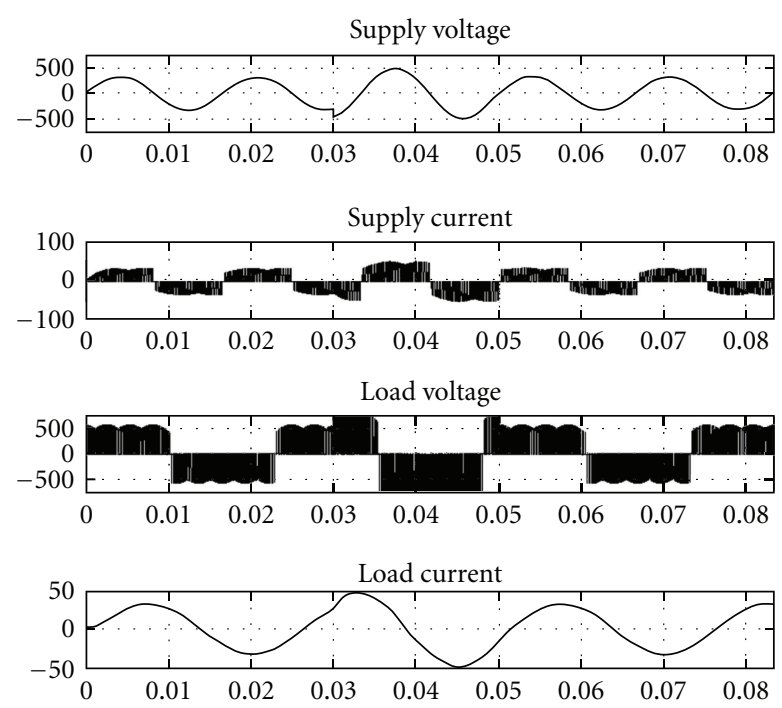

FIGURE 16: Voltage swell accord in matrix converter output current, voltage without compensation. 


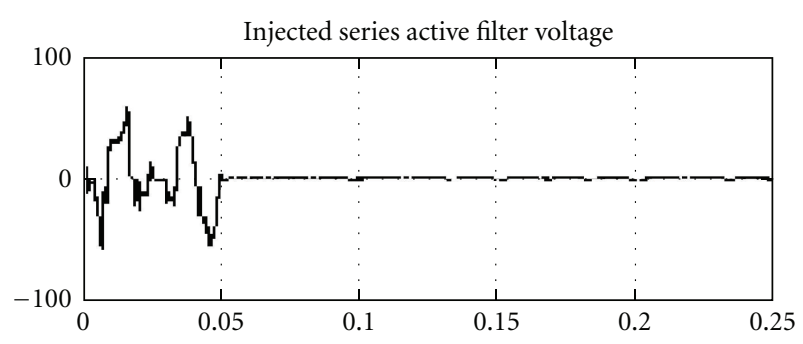

FIGURE 17: Injected series active voltage.
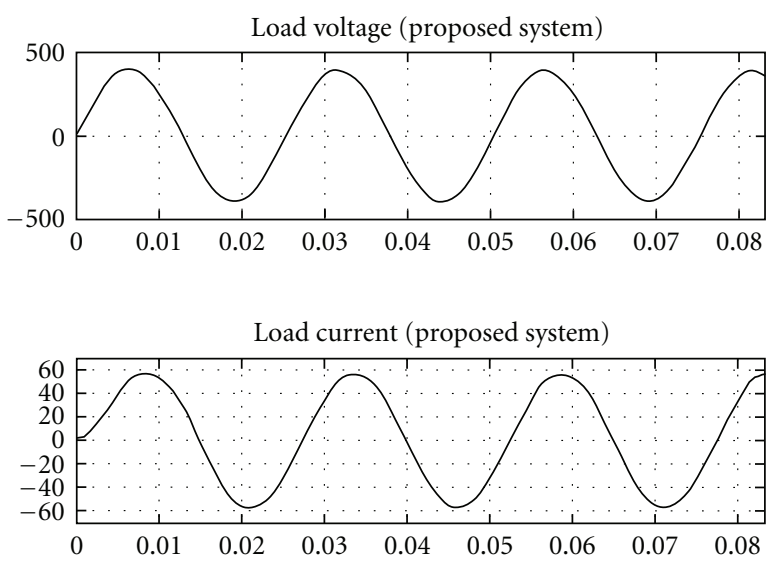

FIGURE 18: Voltage swell accord in matrix converter output current, voltage with compensation.

Figure 14 shows the proposed series active power filter scheme that compensates the load voltage wave shape effectively when compared to the existing system effectively as shown in the simulation results. The total simulation time is $0.01 \mathrm{sec}$ to $0.04 \mathrm{Sec}$.

In Figure 15 shows that the matrix converter output harmonics are $60 \%$. After the proposed series active filter is implemented the matrix converter output voltage harmonics reduced by $3 \%$ as shown. Figure 17 shows the input harmonics voltage produced, that is, the matrix converter affected by swell. The simulation result has shown, the matrix converter reflected the input supply variation to output. After the series active filter, turned on, the swell voltage is compensated. Figure 16 shows when the matrix converter is affected by swell. The voltage swell presents at 0.03 to $0.05 \mathrm{sec}$.

Figure 17 shows the compensated voltage when the swell voltage occurred. The compensated voltage is $45 \mathrm{v}$ this voltage subtracted in the supply by the series active filter.

After that the proposed compensation series active filter eliminate the swell problem and maintains the power quality in the matrix converter output as shown in Figure 18.

\section{Conclusion}

In this paper series active and shunt active filter compensation method compensation are implemented in the matrix converter output for power quality improvement. When
Active Power Filter system is operated in matrix converter, the supply harmonics are removed effectively compared to the fixed capacitors.in simulation studies, the results are specified before and after active power filter system is operated. In the proposed new strategy it can eliminate $80 \%$ of harmonic components. When Active Power Filter system is operated in matrix converter, the load harmonics are removed effectively. The modification of this proposed methodology has good simulation results as compared with the conventional harmonic control method. The proposed method is validated and the simulation results are obtained through MATLAB/Simulink software.

\section{References}

[1] A. Kusko and M. T. Thomsom, Power Quality in Electrical System, chapter 1, McGraw Hill, New York, NY, USA, 2007.

[2] R. Yacamini and J. C. de Oliveira, "Harmonics produced by direct current converter transformers," The Proceedings of the Institution of Electrical Engineers, vol. 125, no. 9, pp. 873-878, 1978.

[3] D. Casadei, G. Serra, A. Tani, and P. Nielsen, "Theoretical and experimental analysis of SVM controlled matrix converters under unbalanced supply conditions," Electromotion Journal, vol. 4, pp. 28-37, 1997.

[4] H. Alyun, "Implementation of a single-phase matrix converter induction motor drive," Electrical Engineering, vol. 90, no. 6, pp. 425-433, 2008.

[5] P. W. Wheeler, H. Zhang, and D. A. Grant, "A theoretical and practical investigation of switching frequency harmonics in a matrix converter," in Proceedings of the International Universities Power Engineering Conference (UPEC '93), pp. 502-505, 1993.

[6] J. Karpagam, A. Nirmal Kumar, and V. Kumar, "Chinnaiyan comparison of modulation techniques for matrix converter technology," IACSIT International Journal of Engineering and Technology, vol. 2, no. 2, 2010.

[7] N. R. Zargari, G. Joos, and P. D. Ziogas, "Input filter design for PWM current-source rectifiers," in Proceedings of the 8th Annual Applied Power Electronic Conference and Exposition (APEC'93), pp. 824-830, March 1993.

[8] L. Huber and D. Borojevic, "Input filter design of forced commutated cycloconverters," in Proceedings of 6th Mediterranean Electrotechnical Conference, vol. 2, pp. 1356-1359, 1991.

[9] N. R. Zargari, G. Joos, and P. D. Ziogas, "Input filter design for PWM current-source rectifiers," in Proceedings of the 8th Annual Applied Power Electronic Conference and Exposition (APEC'93), pp. 824-830, March 1993.

[10] M. L. Heldwein and J. W. Kolar, "Impact of EMC filters on the power density of modern three-phase PWM converters," IEEE Transactions on Power Electronics, vol. 24, no. 6, pp. 1527$1588,2009$.

[11] J. Biela, A. Wirthmueller, R. Waespe, M. L. Heldwein, and K. Raggl, "Passive and active hybrid integrated EMI filters," IEEE Transactions on Power Electronics, vol. 24, no. 5, pp. 13401349, 2009. 

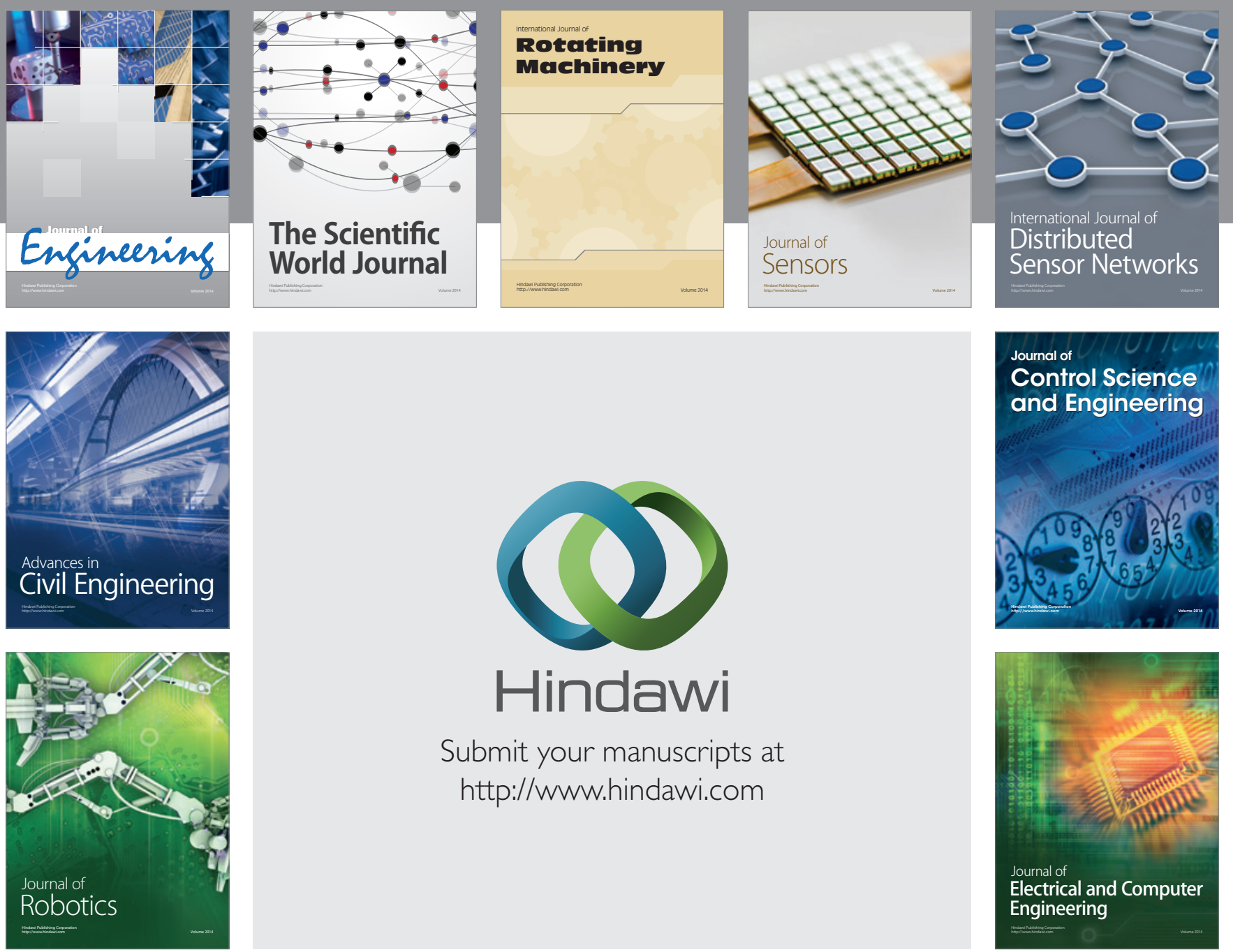

Submit your manuscripts at

http://www.hindawi.com
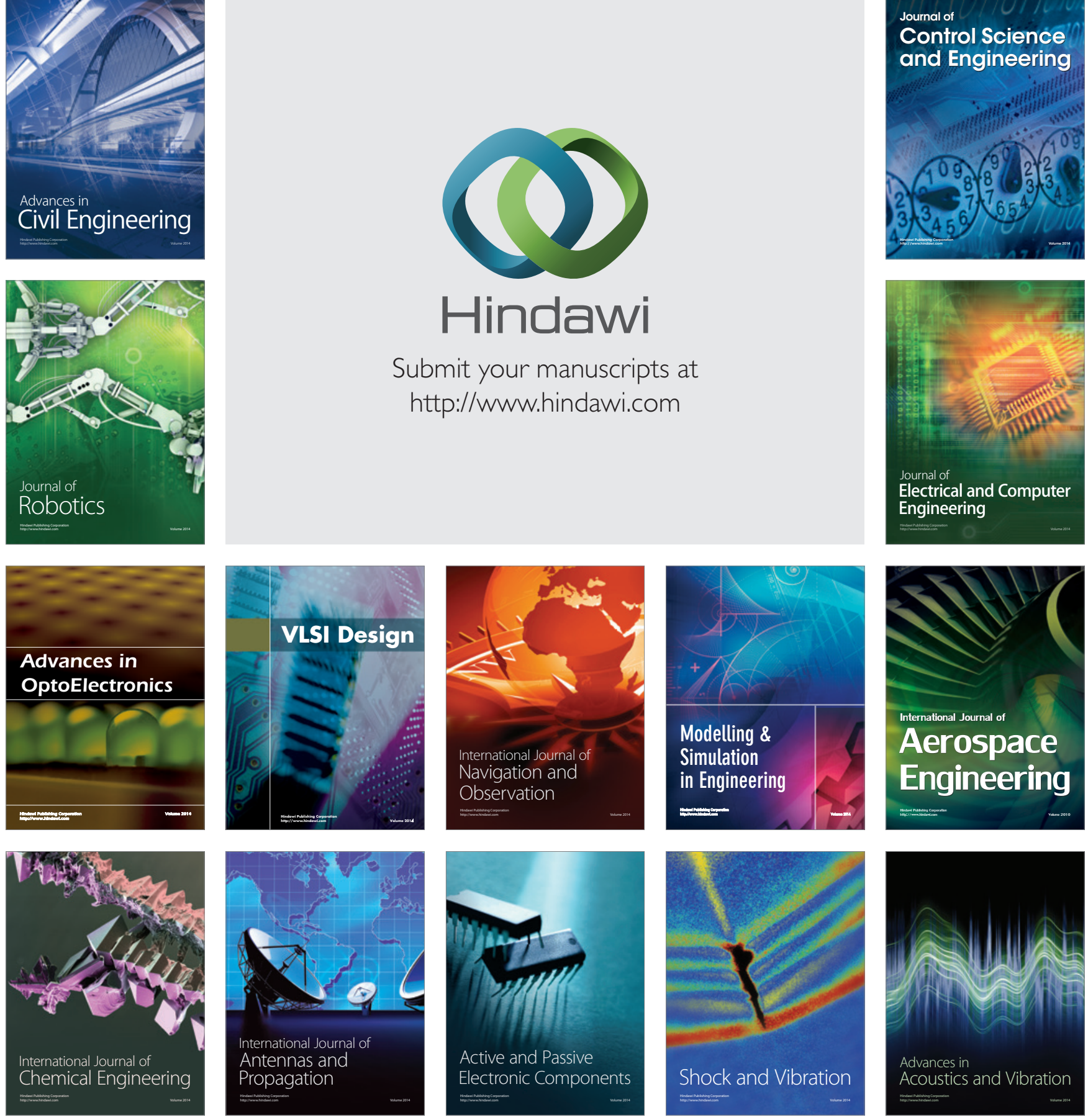